\title{
Lazer Taramalı Konfokal Mikroskobun Prensipleri ve Tipta Kullanım Alanları
}

\section{Principles of Laser Scanning Confocal Microscope and Applications in Medicine}

\author{
Zeynep Betül SARI \\ Selçuk Üniversitesi, İleri Teknoloji Araştırma ve Uygulama Merkezi , Konya, Türkiye
}

Yazışma Adresi

Correspondence Address

Zeynep Betül SARI

Selçuk Üniversitesi, İleri Teknoloji Araştırma ve Uygulama Merkezi, Konya, Türkiye

zeynep41985@yahoo.com

Geliș tarihi / Received : Ağu 18, 2020 Kabul tarihi / Accepted : Kas 30, 2020 Elektronik yayın tarihi : Eyl 01, 2021 Online published

Bu makalede yapilacak atıf: Cite this article as:

Sarı ZB.

Lazer Taramalı Konfokal

Mikroskobun Prensipleri ve Tipta Kullanım Alanları

Akd Tip D / 2021; 7(3):457-462

Zeynep Betül SARI

ORCID ID: 0000-0003-0378-7673

\section{ÖZ}

Floresan mikroskobunun gelişimi, lazer taramalı konfokal mikroskobunun icadı ile devrim yapmıştır. Üç boyutlu gösterim ve analiz teknikleriyle bu teknoloji özellikle tıp/biyomedikal dünyasına daha gerçek bir bakış sağlamıştır. Konfokal mikroskobu, üç boyutlu yapıya sahip floresan işaretli numunelerin görüntülenmesi için bir ışı mikroskobi tekniğidir. Konfokal mikroskop uygulamaları; fikse edilmiş veya canlı hücrelerde makromoleküllerin uzamsal dağılımının görüntülenmesini, üç boyutlu verilerin toplanmasını, çoklu floresan ile işaretlenmiş örneklerin görüntülenmesini ve canlı hücrelerdeki fizyolojik olayların ölçülmesini içerir. Bu derlemede, lazer taramalı konfokal görüntülemenin prensipleri, tarihçesi, diğer mikroskoplardan ayrılan özellikleri, ayrıca yenilikçi ve önemli yönleri ve tıpta kullanım alanları sunulmaktadır.

\section{Anahtar Kelimeler:}

Lazer taramalı konfokal mikroskop, Floresan mikroskop, Mikroskopi

\begin{abstract}
The development of the fluorescent microscope is revolutionized with the invention of laser scanning confocal microscopy. With its three-dimensional display and analysis techniques, this technology has provided a more real view of the medical / biomedical world. Confocal microscope is based on a light microscopic technique for imaging fluorescently labeled samples with a three-dimensional structure. Confocal microscope applications include imaging the spatial distribution of macromolecules in fixed or live cells, collecting three-dimensional data, displaying multiple fluorescently labeled samples, and measuring physiological events in living cells. In this review; the principles of the laser scanning confocal imaging, history of confocal microscopy, features distinguished from other microscopes, as well as its innovative and important aspects and applications to medicine are presented.
\end{abstract}

\section{Key Words:}

Laser scanning confocal microscope, Fluorescence microscope, Microscopy

\section{GIRIŞ}

'Bir resim binlerce kelimeye bedelken bir video milyonlarca kelimeye bedeldir' ifadesi ile görüntülemenin önemi vurgulanmıştır (1). Tarihte bu görüntüleme girişimlerinin başlangıcı R. Hooke'un çalışmaları olarak kabul edilir. Hooke'un mikroskobu ile bugünkü modern 
mikroskopların arasında görüntülemenin temel prensibini oluşturan fizik kanunları aynıdır $(2,3)$. Aydınlık saha ve karanlık saha mikroskopları, faz-kontrast mikroskobu, nomarski görüntülemesi, ters (inverted) mikroskop, elektron mikroskopları olan transmisyon elektron mikroskobu (TEM) ve scanning elektron mikroskobu (SEM), floresan ve konfokal mikroskop gibi çok çeşitli mikroskop çeşitleri vardır. Bunların arasından konfokal mikroskop doku ve hücreleri görüntülemede ileri mikroskopi türlerinden birisidir. Lazer taramalı konfokal mikroskobunun (LTKM) icadı floresan mikroskobunun gelişimine bağlıdır. Floresan mikroskobu 1904'te icat edilmiş ve 1941 'de, floresan işaretli antikorlar kullanılmasına rağmen (4), cihaz ve reaktifleri 1970'lere kadar gerçekten etkili bir şekilde bir araya gelmedi. $\mathrm{Bu}$ belki de antikorların sadece enfeksiyon incelemesi için yararlı olduğuna dair yanlış bir düşünceden kaynaklanıyordu. Aktin ve tübülin gibi normal proteinlere karşı antikorların çoğaltılabilmesi sürpriz bir gelişmeydi (5). Antikorlara bağlı floresan boyalar hücrelere uygulandı ve hücre iskeletinin ayrıntılı mimarisini ortaya çıkardı ve 1970'lerin sonları ve 1980'lerin başında bilim camiasında tartışma ve şaşkınlığa neden oldu. Aynı dönemde, kalsiyum iyonu konsantrasyonu gibi önemli hücre içi parametrelere cevap veren floresan boyaları da kullanıma girmiştir (6). Daha sonra, floresan mikroskopları ile, biyokimya ve elektrofizyoloji gibi alanlarda görüntüleme artmaya başladı. O zamanlar hücre biyolojisinde yayınlanan tüm çalışmaların büyük bir kısmı, belki de yarısı, floresan tekniğine dayanıyordu. 1984'e gelindiğinde, yöntemin başlıca sınırlaması belirginleşti; kalın bir örneğin odak dışı kısımları, ince yapıların ayırt edilemediği düzgün bir 1şıltıya neden oluyordu. Birçok araştırmacı, çalışmalarını ince ve düz hücrelerle sınırlandırarak bu sorunu çözdü. Daha net bir görüş elde etmek amacıyla mikroskobu geliştirmek için bir yol bulunmalıydı (7).

Bu bağlamda mikrosinematografi ve sonra video mikroskopi biyolojik fenomene büyük bir ilerleme getirmiştir. Ancak bu teknolojilerin, görüntüleri üç boyutlu elde edememesinden kaynaklı sınırlayıcı yanı vardır. Pek çok preparat, kültüre edilmiş hücrelerden veya dokulardan hazırlanmaktadır ki bunlar da oldukça kalın kesitlerdir. İlk konfokal mikroskobunun gelişimi canlı organizmaların dokularında gözlem yapmayı hedeflemektedir. Konfokal mikroskobunun optik kesit alabilme özelliği sayesinde kalın örneklerle çalışılabilmektedir. Konfokal mikroskobu non-iyonize 1 şı ğ kullandığı için yaygınlaşmakta ve canlı hücreler ve doku preparatlarında kullanımı artmaktadır (8). Bu derlemede lazer taramalı konfokal mikroskop görüntülemenin prensipleri, tarihçesi, diğer mikroskoplardan ayrılan özellikleri, ayrıca yenilikçi ve önemli yönleri ve tıpta kullanım alanları sunulmaktadır.

\section{Konfokal Mikroskobu Nedir?}

Lazer taramalı konfokal mikroskobu, fokal düzlemden (odak düzlem; bir kaynaktan -1sı veya 1şık- yayılan 1şınların toplandığ1 düzlem) daha kalın örneklerdeki odak dışı 1Şı ̆̆ $1 /$ parlaklığı elimine etmek için uzaysal filtrelemeyi kullanarak kontrastı artırmak ve üç boyutlu görüntüyü oluşturmak için kullanılan optik görüntüleme tekniğidir. Lazer ışınlarının ve bilgisayarın birleştirilmesiyle elde edilen görüntünün değerlendirilmesi ve üç boyutlu görüntülerle hücre içi çalışmaları ortaya koyan bir mikroskop türü şeklinde de tanımlanabilir. Ya da kısaca floresan mikroskop prensiplerine benzer çalışan bir mikroskoptur (9).

\section{Tarihçe}

Konfokal mikroskobuna 1955'te Harward Üniversitesi'nde burslu öğrenci olan Marvin Minsky öncülük etmiştir. Örnekten çıkan 1 şık, fokal noktadan direkt gelmeyen 1şınları geri çevirecek olan ikinci bir delikten geçecektir. Geriye kalan istenen 1 şı 1şınları daha sonra foton çoğaltıcı tüp ile toplanacak ve görüntü tekrar inşa edilecektir. Görüntüyü oluşturmak için Minsky, örneği 1şı 1şınlarındansa mikroskopta bakılacak nesnenin konulduğu lamı hareket ettirerek taradı. Platformu dikey ve yatay hareket ettirerek her 10 saniyede yaklaşık bir görüntü elde etmeyi planladı (10).

Konfokal yaklaşımının gelişimi, canlı dokularda biyolojik olaylar oluyorken görüntü alma isteğinden büyük ölçüde yön bulmuştur ve Minsky'nin amacı da zaten canlı beyninin boyanmamış preparatlarında nöral ağları görüntülemekti. Minsky tarafindan geliştirilen ve $1957^{\prime}$ de patentlenen konfokal görüntülemenin prensibi tüm modern konfokal mikroskoplarda uygulanmaktadır. İlk ışın taramalı konfokal mikroskobu canlı organizmaların dokularında gözlem yapmak için kullanılmıştır (11). Canlı hücrelerin konfokal mikroskobu zor olmasına rağmen kullanımı 23 yıl önce iki öncü çalışmayla gösterilmiştir. Cornel-Bell ve arkadaşları, büyük bir keşif yapmak için astroglialarda glutamat stimüle transcellular $\mathrm{Ca}+2$ değişimini gözlemek için konfokal mikroskobunu kullanmıştır. Aynı yıl konfokal mikroskobu, nöronal aksonlar ve kurbağa yavrusunun beyin gelişimindeki büyüme konilerini görüntüleyerek gelişimsel değişiklikler karakterize edilmiştir (12). Bu iki öncül çalışmadan itibaren konfokal mikroskobunun farklı biyolojik preparatlarda dinamik süreçleri çalışmak için kullanımı artmıştır.

Pek çok teknolojik ilerleme, Minsky’nin konfokal prensibine katkı sağlamıştır. Gelişmiş nokta 1şık kaynağı için çok dalgalı lazerler, gelişmiş iki yönlü kromatik aynalar, duyarlı düşük gürültülü fotodedektörler, görüntü alımında hızlı mikrobilgisayarlar, görüntü analiz yazılım programları ve yüksek çözünürlüklü video gösterisi ve dijital görüntü yazıcıları bu gelişmeler olarak sayılabilir. $\mathrm{Bu}$ teknolojiler birbirinden bağımsız olarak gelişmektedir ve konfokal görüntüleme sistemlerine 1955 'ten beri eklenmektedir. Bir örnek olarak dijital görüntüleme prosesleri ilk defa 1980'lerin başında Woods Hole Oceanografik Enstitüsü'nde etkili bir şekilde uygulanmıştır. Video geliştirilmiş mikroskoplar (video-enhanced microscopes) olarak adlandırdıkları mikroskopları kullanarak mikrotübül gibi hücresel yapıları görüntüleyebilmektedir (8).

\section{Neden Konfokal Mikroskobu Tercih Edilir?}

Konfokal Mikroskobu, odak dışındaki ışığı elimine ederek hücre ve dokuların yüksek çözünürlüklü floresan görüntülerini alır. Böylece arka plandan gelen net olmayan floresan 
görüntüyü ortadan kaldırır (Şekil 1).

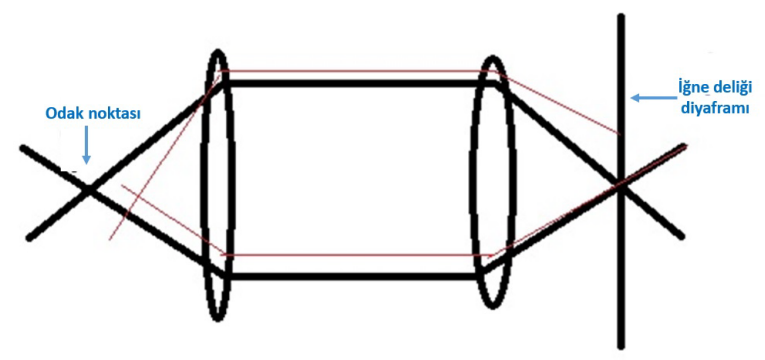

Şekil 1. Odak düzlemden gelmeyen 1şığın geri çevrilişi/yadsıması.

Odak düzlemden gelip ekrana ulaşan tüm 1şık (koyu mavi 1şık) bu yolu izlemektedir. Odak düzlemden gelmeyen 1 şı (açık mavi) ise yadsımaktadır. Bir görüntünün oluşması için noktaların odakta olması gerekmez. Konfokal mikroskobunda amaç yalnızca koyu mavinin görüntüsünü iğne deliği diyaframı sayesinde göstermektir. Net olmayan sinyallerin kaldırılması ile kontrast ve çözünürlük artar. Görüntüde daha az belirsizlik/bulanıklık ve daha iyi kontrast vardır. Konfokal mikroskobunun kullanımında klasik optik mikroskoplara kıyasla yüksek kalitede görüntü eldesi ve pek çok araştırma alanında kullanılıyor olmasından dolayı son yıllarda müthiş bir patlama olmuştur (10).

\section{Neden Konfokal Olarak Adlandırılmıştır?}

Klasik floresan mikroskobunda tüm örnek, 1şık kaynağından gelen 1şıkla tamamen dolar. Bu nedenle optik yolak vasıtasıyla örneğin tüm kısımları uyarılacaktır. Konfokal mikroskobu ise fokal düzlemin haricindeki bilgiyi elimine etmek için optik olarak konjuge düzlemdeki dedektörün önüne optik olarak nokta aydınlatma ve iğne deliği diyaframı kullanır (10).

\section{Modern Konfokal Mikroskobu}

Modern konfokal mikroskobu, Minsky’nin dizayn ettiği anahtar elementleri kapsamaktadır (Şekil 2);

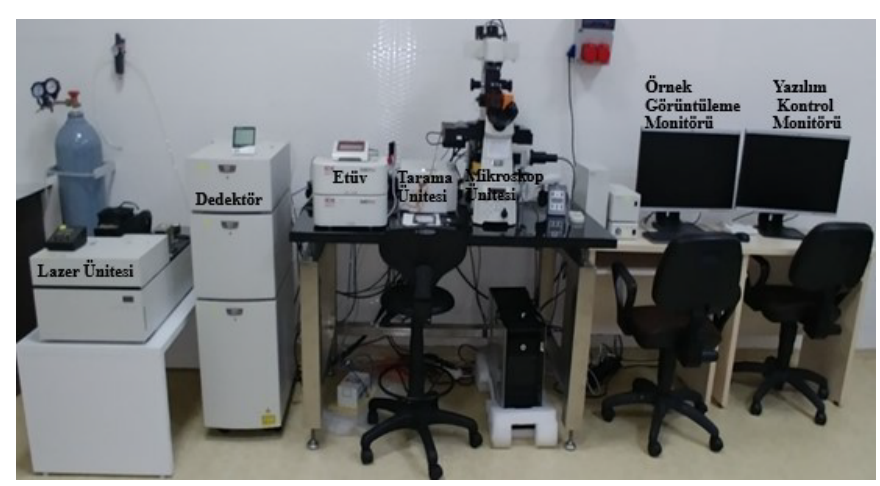

Şekil 2. Modern Konfokal Mikroskop (Selçuk Üniversitesi İleri Teknoloji Araştırma ve Uygulama Merkezindeki Lazer Taramalı Konfokal Mikroskop).

iğne deliği diyaframı ve örneğin noktası noktasına çekimi, optik ve elektronikteki gelişmeler son dizaynlarla birleşmiştir ve oluşturulan görüntülerin hızı, kalitesi ve depolanmasıyla ilgili gelişmeler sağlamıştır (9).

\section{Konfokal Mikroskop Çalışma Prensibi}

Konfokal mikroskopların çoğu görüntüyü ya örnekten 1şığ yansıtarak ya da örneğe uygulanan boyalardaki (florofor) floresanları uyararak oluşturmaktadır. Biyolojik uygulamalarda en fazla kullanılan konfokal mikroskobuna yoğunlaşılacaktır. Konfokal mikroskobunu anlamanın yolu floresan mikroskobunu anlamadan geçmektedir. Konfokal mikroskop, numunenin noktası noktasına aydınlatılması ve odak dışı 1şı̆̆ın reddini sağlar (Şekil 3).

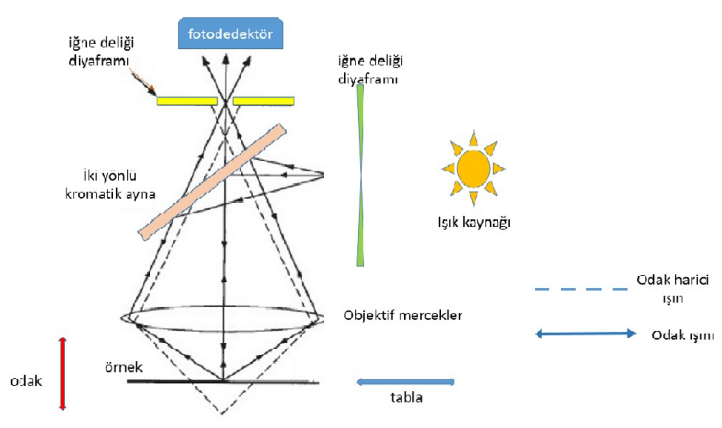

Şekil 3. Konfokal mikroskopta izlenen ışık yolu.

Numune üzerinde bir nokta görüntülemenin bir dezavantaj1, herhangi bir anda toplanacak daha az yayılan fotonun mevcut olmasıdır. Bu nedenle, gürültülü bir görüntü oluşturmaktan kaçınmak için her nokta, doğru bir ölçüm yapmak için yeterli 1şık toplamak üzere uzun süre aydınlatılmalıdır (13). Bu sorunu, Minsky zirkonyum ark lambası ile yaptığı çok yüksek yoğunluklu bir 1şık kaynağı kullanarak çözmektedir. Modern çözüm ise çok çeşitli dalga boylarına sahip bir lazer 1 şı kaynağıdır. Lazer yoğun uyarma ışı̆̆ı sağlar. Işık, dikey ve yatay tarama aynalarına yönlendiren bir dikroik aynaya yansitılir. Bu motorlu aynalar lazeri örnek boyunca tarar. Minsky'nin buluşu, optikleri sabit tutuyor ve bunun yerine tablayı dikey ve yatay yönde ileri geri hareket ettirerek örneği tarıyordu. Numune, tarama aynası konfigürasyonunda olduğu gibi farklı açılardan ziyade eksen doğrultusunda aydınlatılır ve böylece optik sapmalardan kaçınır. Böylece, tüm görüş alanı aynı şekilde aydınlatılır. Numunedeki boya lazer 1şı̆̆ı ve floresanlarla uyarılmaktadır. Floresan 1şık, lazerden uyarma 1şı̆̆ını taramak için kullanılan aynanın aynısı ile çözülür ve daha sonra dikroik aynadan geçer. Daha sonra iğne deliği diyaframı odaklanır. İğne deliği diyaframdan geçen 1 şık, foton çoklayıcı tüp gibi bir dedektör tarafından ölçülür. Konfokal mikroskopta, numunenin hiçbir zaman tam bir görüntüsü yoktur, çünkü herhangi bir anda sadece bir nokta gözlenir. Böylece, görselleştirme için dedektör, görüntüyü bir seferde bir piksel oluşturan bir bilgisayara bağlanır. $512 \times 512$ piksel görüntü için bu genellikle 0,1-30 Hz kare hızında yapılır. Mikroskop tarafından oluşturulan görüntü, örneğin kesitin optik kesit olarak adlandırılan ince bir düzlemsel bölgesidir. Düzlem dışı odaklanmamış 1şık reddedilerek, böylece daha keskin ve daha iyi çözülmüş bir görüntü elde edilir (10). 


\section{Konfokal Mikroskobunun Tipta}

\section{Kullanım Alanları}

Konfokal mikroskobunun geniş uygulamaları nöroanatomi ve nörofizyoloji çalışmaları, hücre ve dokunun morfolojik çalışmaları ve tıpta tanı ve tedavide kullanımı gibi çok çeşitli çalışmaları kapsamaktadır. Konfokal mikroskobunun yaygın kullanımı olarak canlı hücre görüntüleme, Yeşil Floresan Protein kullanarak hücre ve doku içi protein trafiğini görüntüleme, işaretlenebilen protein, gen gibi yapıları ve onların hareket ve pozisyonlarını görüntüleme, hibridizasyon ve floresan Polimeraz Zincir Reaksiyonu (PZR)'nin de kullanıldığı kromozom üzerindeki gen lokalizasyonlarını saptamada; subsellüler fonksiyonu analiz etmede, hücre içi iyon konsantrasyonunun değişimlerini ölçme sayılabilir. Diğer uygulama alanları ise rezonans enerji tansferi, kök hücre araştırması, foton ile soldurma çalışmaları, aralıklı görüntüleme, multifoton mikroskopisi, total internal refleksiyon, membran ve iyon problar1, bioluminesan proteinleri ve epitop etiketleme çalışmalarıdır $(14,15)$.

Konfokal mikroskobunun tıpta özellikle tanı ve tedavi amaçlı yeni kullanım alanları da şunlardır; tıpta kullanılan monoklonal antikorlar dünyasında, yapılar arasındaki mesafelerin daha niceliksel analizine ve çeşitli hücresel bölümlerde bunların tespit edilmesi gibi çalışmalarda kullanılmaktadır. Örneğin biyolojik olarak bozunabilir mikroküreler içindeki insan immünoglobulin $\mathrm{G}$ (IgG) homojen ilaç dağılımını ortaya çıkarmak için LTKM kullanılmıştır ve salım profilleri karakterize edilmiştir. LTKM ayrıca mikropartiküller ve jellerdeki makromoleküllerin difüzyon katsayılarını ölçmek için de kullanılmıştır (16). İnsan IgG, yabancı hücrelere ve ajanlara karşı hazır bir savunma sağlar; konjenital veya edinilmiş hipogama-globulinemili hastalar için replasman tedavisinde ve kanser, nefropati ve gastrointestinal hastalarının sekonder IgG eksikliklerinin tedavisinde kullanılır. Kontrollü iletim sistemleri, intravenöz ve intramüsküler uygulamanın klasik yöntemlerinin yerini almaktadır. Bu tür sistemler lokalize ilaç iletimi, tedavi sıklığındaki azalma, azaltılmış maliyetler, hasta uyumundaki iyileşme ve azalan yan etkiler nedeniyle caziptir (17). $\mathrm{Bu}$ amaçla biyolojik olarak bozunabilir polimer mikroküreleri, insan klinik kullanımı için onaylanmıştır. Mikropartikülat antijen verme sistemleri, kararlı taşıyıcılar ve aşılar için etkili adjuvanlar olarak özel öneme sahiptir (18). Dolayısıyla bu teknolojideki gelişmeler insan sağlığını, tedavi şekillerini ve sonuçlarını doğrudan etkileyecektir. LTKM, ayrıca bir başka çalışmada L929 fibroblastlarında titanyum birikimini göstermiştir (19). Bu LTKM uygulamaları, görüntüleme sistemlerine ihtiyaç olduğunu göstermekte ve yüksek kaliteli görüntüleme verilerine olan talep artmaktadır. Konfokal mikroskobu, hücreler ve zarlardaki floresan molekül topluluklarını incelemek için yaygın olarak kullanılmaktadir (1).

Endometriyal hücrelerin mezotelyuma yapışmasını ve invazyon sürecini gösteren ilk zaman aşamalı çalışmanın, üç boyutlu LTKM kullanılarak yapıldığı bildirilmiştir (20). Günümüzde görüntüleme teknolojileri prosedürleri, kompleks numunelerde eksprese edilmiş genlerin ve proteinlerin kantitatif ve tekrarlanabilir analiz taleplerini karşılamaktadır.
LTKM veri toplama, yüksek uzaysal ve zamansal çözünürlüğe sahip canlı deniz kestanesi embriyolarında gen ekspresyon düzeylerinin saptanması için kullanılmıştır (21).

Son zamanlarda, LTKM çok bileşenli supramoleküler hidrojel sistemlerinin yapısal analizi için de güçlü bir araç olarak ortaya çıkmıştır (22). Çünkü bu çok bileşenli supramoleküler hidrojellerin yapımını sağlamak için, bunların derinlemesine karakterizasyonu çok önemlidir (23). Rejeneratif tıp ve kontrollü ilaç salımı ve dağıtım sistemlerinde uygulamalara olanak tanıyan çok çeşitli fonksiyonel moleküller (proteinler, katalizörler ve nanomalzemeler), işlev kaybı olmaksızın hidrojellere (çok bileşenli hidrojel sistemleri olarak adlandırılır) dahil edilebilir (24). LTKM, numuneleri supramoleküler nanofiberlerin ve hidrojellerin gözlemlenmesine izin vermekle kalmaz, aynı zamanda uygun şekilde tasarlanmış floresan probların kullanılmasıyla kimyasal türleri ayırt edebilir (25). Konfokal floresan görüntüleme ve ilgili mikroskobik teknikler; supramoleküler kimya, sistem kimyası ve denge dışı kimya kombinasyonu ile gerçekleştirilen karmaşık, yaşamdan ilham alan kimyasal sistemlerin araştırılması için firsatlar sağlamaktadır (26).

Konfokal mikroskobu ile ayrıca; cilt biyopsisi ve fiziksel kesitsiz subselüler, yüksek çözünürlüklü görüntüler üreterek hızlı, yatak başı patolojik analizler yapılmaktadır $(27,28)$. Bu görüntüleme reflektans (yansıma) konfokal mikroskobuyla sağlanmaktadır. Reflektans konfokal mikroskobik görüntüleme, girişimsel olmayan bir şekilde insan cildinde (in vivo) hücresel düzeyde morfolojiyi gösterir. Epidermisin ve alttaki papiller dermisin, tipik olarak $0,5 \times 0,5 \mathrm{~mm} 2$ 'lik ve 100-200 $\mu$ m'lik derinliklere kadar 2-5 $\mu$ m'lik optik kesit ve 0,5-1,0 $\mu$ m'lik çözünürlükle, küçük görüş alanlarında görüntülenmesi rutin olarak gerçekleştirilir (29). Reflektans konfokal mikroskop görüntülemenin başarısı, gelişmekte olan diğer tüm girişimsel olmayan optik teknolojilerin yolunu açmaktadır (30).

Lazer teknolojisindeki son gelişmeler, hücresel düzeyde in vivo görüntüleme sağlamak için konfokal floresan mikroskobu prensibini kullanan mikroendoskopik cihazların geliştirilmesini kolaylaştırmıştır (31). Konfokal lazer endomikroskobu; konfokal mikroskobunun, 1000x büyütme ile mikron düzeyinde uzamsal çözünürlük sağlayan düşük güçlü bir lazerle doku aydınlatmasına dayanan bir çeşididir. Kolorektal kanser ve premalin lezyonların hızlı bir şekilde saptanmasında kullanılır (32). Dokunun histopatolojisini yüksek duyarlılık ve doğrulukla tahmin ederken; neoplazmların non-neoplazmalardan, gelişmiş adenomların gelişmiş olmayan adenomlardan ve adenomatöz poliplerin adenomatöz olmayan poliplerden ayrılmasında kullanılır (33). Hem üst hem de alt mide bağırsak yolunda çok sayıda hastalıkta ve son zamanlarda safra kanalı, pankreas ve karaciğerin görüntülenmesinde çalışılmıştır. Patofizyoloji ve moleküler in vivo görüntülemeyi mümkün kılar, böylece temel ve klinik bilim anlayışımızı genişletir (34). Prob tabanlı konfokal lazer endomikroskobu da, geleneksel in situ hücresel karakterizasyona önemli bir alternatif olarak kısa sürede yükselmektedir (31). Son yıllarda LTKM, farklı derinliklerde oküler yüzey dokularının in vivo biyopsisine ve hücresel ve hücre altı düzeyde 
doku analizine de imkân vermiștir. Yakın zamana kadar, oküler yüzey yapılarının mikroanatomi değerlendirilmesi, yüzeysel epitel katmanlarının örneklenmesine dayanan impresyon sitolojisiyle sinırlıydı. Örneğin meibomius bezi, konfokal değerlendirmeden en çok yararlanılan oküler yüzey yapılarından biridir, çünkü standart meibografi sadece tüm bezin makroskopik bir analizini verebilir. Konfokal mikroskobu ile ise, potansiyel olarak bezlerde sorun oluşmadan önce teşhisine izin verebilir. Ayrıca, konfokal mikroskobu girişimsel olmayan bir yöntem olduğu için hastalara rahatsılılk vermediğinden, bu teknik hastalığı zaman içinde sıkı bir şekilde izleme, gerektiğinde tedaviyi tahmin etme, tedaviye yanıtı izleme ve buna göre tedavi rejimini değiştirme avantajı sunar. Oküler yüzey hastalıkları insidansının son yıllarda katlanarak arttığı düşünüldüğünde konfokal mikroskobunun önemi daha iyi anlaşılacaktır (35).

\section{SONUÇ}

Lazer taramalı konfokal mikroskobu, başta tıp olmak üzere biyolojik, biyomedikal, gıda gibi bilim alanlarındaki araştırmalarda değerli bir alet olmaya başlamış ve kullanımı hızla yaygınlaşmaktadır. Tıp dünyasında da tanı ve tedavi için kullanımı giderek yaygınlaşmaktadır. Kanserli dokuların erken teşhisinden, tanıda kesinliği sağlamasına kadar yeni katkıları vardır. Geleneksel mikroskoplara göre daha keskin, daha ayrıntılı iki boyutlu görüntüler oluşturur ve üç boyutlu veri toplanmasına izin verir. Ancak bazı eksiklikleri için konfokal mikroskobuna daha ileri özellikler kazandırılmaya çalışılmaktadır. Bu bağlamda teknoloji, canlı örneklere daha derin penetrasyon imkânı veren konfokal mikroskoba kombine çoklu foton görüntülemenin getirilmesiyle hızlı bir şekilde gelişmeye devam etmektedir. Bu özellik, gelişmiş problarla birleştiğinde konfokal mikroskobun, hücrelerdeki makromoleküllerin uzamsal dağılımını ve davranışını görüntülemeye yönelik güçlü bir araç olmasını sağlamaktadır.

\section{KAYNAKLAR}

1. Pawley J (ed): Handbook of biological confocal microscopy. Springer Science \& Business Media, 2006.

2. Paddock SW (ed): Confocal microscopy methods and protocols. Humana Press, 1998.

3. Murphy DB (ed): Fundamentals of light microscopy and electronic imaging. New York, John Wiley \& Sons, 2002.

4. Kasten FH, The origins of modern fluorescence microscopy and fluorescent probes, in Cell structure and function by microspectrofluorometry. Elsevier 1989; 3-50.

5. Lazarides E, Weber K. Actin antibody: the specific visualization of actin filaments in non-muscle cells. Proceedings of the Nationa 1974; 71(6): 2268-72.

6. Tsien R, Rink T, Poenie M. Measurement of cytoso lic free $\mathrm{Ca} 2+$ in individual small cells using fluores cence microscopy with dual excitation wavelengths. Cell calcium 1985; 6(1-2): 145-57.

7. Amos WB, White JG. How the confocal laser scanning microscope entered biological research. Biology of the Cell 2003; 95(6): 335-42.

8. Dailey ME, Manders E, Soll DR, Terasaki M. Confo cal microscopy of living cells. In: Pawley JB, ed. Handbook Of Biological Confocal Microscopy Confocal Microscopy of Living Cells. 3th ed. Springer, 2006: 381-403.

9. Paddock SW, Principles and practices of laser scanning confocal microscopy. Molecular Biotech nology 2000; 16(2): 127-49.

10. Semwogerere D, Weeks ER. Confocal microscopy. In: Gary E. Wnek, Gary L. Bowlin, eds. Encyclope dia of Biomaterials and Biomedical Engineering. 5th ed. W. Freeman, C.N. York, 2005: 23: 1-10.

11. Petran M, Hadravsky M, Benes J, Boyde A. In Vivo Microscopy Using the Tandem Scanning Microscope a. Annals of the New York 1986; 483(1): 440-7.

12. O'Rourke NA, Fraser SE. Dynamic changes in optic fiber terminal arbors lead to retinotopic map forma tion: an in vivo confocal microscopic study. Neuron 1990; 5(2): 159-71.

13. Minsky M, Memoir on inventing the confocal scanning microscope. Scanning 1988; 10(4): 128-38.

14. Jonkman J, Brown CM, Wright GD, Anderson KI, North AJ. Tutorial: guidance for quantitative confo cal microscopy. Nature protocols 2020: 1-27.

15. Földes-Papp Z, Demel U, Tilz GP. Laser scanning confocal fluorescence microscopy: an overview. International immunopharmacology 2003; 3(13-14): 1715-29.

16. Kang J, Schwendeman SP. Determination of diffu sion coefficient of a small hydrophobic probe in poly (lactide-co-glycolide) microparticles by laser scanning confocal microscopy. Macromolecules 2003; 36(4):1324-30.

17. Berg A, Olthuis W, Bergveld P (eds): Micro total 
analysis systems 2000. Springer Science \& Business Media, 2000.

18. Thiele L, Rothen-Rutishauser B, Jilek S, H. Wunder li-Allenspach, H.P. Merkle, and E.J.J.o.C.R. Walter, Evaluation of particle uptake in human blood mono cyte-derived cells in vitro. Does phagocytosis activi ty of dendritic cells measure up with macrophages? Journal of Controlled Release 2001; 76(1-2): 59-71.

19. Osano E, Kishi J, Takahashi Y. Phagocytosis of titanium particles and necrosis in TNF- $\alpha$-resistant mouse sarcoma L929 cells. Toxicology in vitro 2003; 17(1): 41-7.

20. Witz CA, Cho S, Centonze VE, Montoya-Rodriguez IA, Schenken RS. Time series analysis of transmeso thelial invasion by endometrial stromal and epitheli al cells using three-dimensional confocal microsco py. Fertility and sterility 2003; 79: 770-8.

21. Dmochowski IJ, Dmochowski JE, Oliveri P, David son EH, Fraser SE. Quantitative imaging of cis-regu latory reporters in living embryos. PNAS 2002; 99(20):12895-900.

22. Panja S, Adams DJ. Gel to gel transitions by dynam ic self-assembly. Chemical Communications 2019; 55(68): 10154-57.

23. Draper ER, Adams DJ. How should multicomponent supramolecular gels be characterised? Chemical Society Reviews 2018; 47(10): 3395-405.

24. Shigemitsu H, Hamachi I. Design strategies of stimuli-responsive supramolecular hydrogels relying on structural analyses and cell-mimicking approach es. Accounts of Chemical Research 2017; 50(4): 740-50.

25. Pujals S, Feiner N, Delcanale P, Voets I, Albertazzi L. Super-resolution microscopy as a powerful tool to study complex synthetic materials. Nature Reviews 2019; 3(2): 68-84.

26. Kubota R, Nakamura K, Torigoe S, Hamachi I. The Power of Confocal Laser Scanning Microscopy in Supramolecular Chemistry: In situ Real-time Imag ing of Stimuli-Responsive Multicomponent Supra molecular Hydrogels. Chemistry Open 2020; 9(1): $67-79$.
27. Hibler BP, Connolly KL, Cordova M, Nehal KS, Rossi AM, Barker CA, Radiation therapy for synchronous basal cell carcinoma and lentigo malig na of the nose: response assessment by clinical examination and reflectance confocal microscopy. Practical radiation oncology 2015; 5(5): e543-e7.

28. Ulrich, M. and S.J.J.o.b.o. Lange-Asschenfeldt, In vivo confocal microscopy in dermatology: from research to clinical application. Journal of biomedi cal optics 2013; 18(6): 061212.

29. Rajadhyaksha M, González S, Zavislan JM, Ander son RR, Webb RH. In vivo confocal scanning laser microscopy of human skin II: advances in instrumen tation and comparison with histology. Journal of Investigative Dermatology 1999; 113(3): 293-303.

30. Rajadhyaksha M, Marghoob A, Rossi A, Halpern AC,Nehal KS. Reflectance confocal microscopy of skin in vivo: From bench to bedside. Lasers in Surgery and Medicine 2017; 49(1): 7-19.

31. Streba CT, Giltan AM, Gheonea IA, Demetrian A, Şoimu A-V, Săftoiu A, Gruionu G,. Gruionu LG. Utility of confocal laser endomicroscopy in pulmon ology and lung cancer. Rom J Morphol Embryol 2016; 57(4): 1221-7.

32. Pamudurthy V, Lodhia N, Konda VJ. Advances in endoscopy for colorectal polyp detection and classi fication. Baylor University Medical Center Proceed ings 2020. 33(1): 28-35.

33. Shahid MW, Buchner AM,. Heckman MG, Krishna M, Raimondo M, Woodward T, and Wallace MB. Diagnostic accuracy of probe-based confocal laser endomicroscopy and narrow band imaging for small colorectal polyps: a feasibility study. American Journal of Gastroenterology 2012; 107(2): 231-9.

34. Goetz MJE. Confocal laser endomicroscopy: Current indications and future perspectives in gastrointesti nal diseases. Endoscopia 2012; 24: 67-74.

35. Fasanella V, Agnifili L, Mastropasqua R, Brescia L, Staso FD, Ciancaglini M, Mastropasqua L. In vivo laser scanning confocal microscopy of human meibomian glands in aging and ocular surface diseases. BioMed research International 2016; 2016. 